\title{
OPTIMALISASI PENERAPAN PROTOKOL KESEHATAN PADA PEKERJA DI KOTA SURABAYA
}

\section{OPTIMIZATION OF HEALTH PROTOCOL IMPLEMENTATION TO WORKERS IN SURABAYA}

\author{
Dani Nasirul Haqi*1, Shintia Yunita Arini ${ }^{2}$ \\ ${ }^{1,2}$ Departemen Keselamatan dan Kesehatan Kerja, Fakultas Kesehatan Masyarakat, Universitas \\ Airlangga, Kampus C UNAIR Mulyorejo Surabaya, 60115 \\ *e-mail: haqidani92@gmail.com
}

\begin{abstract}
COVID-19 is a disease that caused by SARS-CoV-2 and the transmission of COVID-19 occurs when the droplets from an infected person enter the respiratory tract. COVID-19 cases in Surabaya kept increasing day by day, hence the optimum implementation of health protocols needed to be done, including in the group of workers. Workers were a group at high risk of contracting COVID-19, because there was a high possibility of workers making contact with other people in the workplace. The aim of this community service was to optimize the health protocol implementation to the workers in Surabaya. The methods used in this community service were counseling and online discussion. This activity was in collaboration with Surabaya Manpower Department and RRI Radio. The counselling was given by the lecturers of Airlangga University Public Health Faculty to the workers. The topic was about hazard identification, risk assessment and determining control (HIRADC) related to the optimization the health protocol implementation in the workplace, especially about the COVID-19 controls that could be applied by the workers in the workplace. The online discussion was led also by the lecturers of Airlangga University Public Health Faculty, discussing about questions and obstacles related to the implementation of health protocols in the workplace.
\end{abstract}

Keywords: COVID-19, health protocol, workers

\section{abstrak}

COVID-19 merupakan penyakit yang disebabkan oleh virus SARS-CoV-2 dan penularannya terjadi apabila droplets dari orang yang terinfeksi masuk ke dalam saluran pernapasan. Kasus COVID-19 di Kota Surabaya terus mengalami peningkatan setiap harinya, sehingga penerapan protokol kesehatan secara optimal perlu dilakukan di Kota Surabaya, salah satunya adalah pada kelompok pekerja. Hal ini karena kelompok pekerja merupakan kelompok berisiko tinggi tertular COVID-19 karena adanya kemungkinan yang tinggi pekerja melakukan kontak dengan orang lain ketika berada di tempat kerja. Tujuan dari pengabdian masyarakat ini adalah mengoptimalisasi penerapan protokol kesehatan pada pekerja di Kota Surabaya. Metode yang digunakan dalam kegiatan ini adalah penyuluhan dan diskusi online yang bekerja sama dengan Dinas Tenaga Kerja Kota Surabaya dan media Radio RRI. Kegiatan penyuluhan dilakukan oleh Dosen Fakultas Masyarakat kepada masyarakat pekerja. Materi yang disampaikan adalah hazard identification, risk assessment and determining control (HIRADC) terkait optimalisasi penerapan protokol kesehatan, terutama tentang pengendalian COVID-19 yang dapat diterapkan pekerja di tempat kerja. Kemudian dilakukan diskusi online yang juga dipimpin oleh Dosen Fakultas Kesehatan Masyarakat yang membahas pertanyaan serta kendala terkait penerapan protokol kesehatan di tempat kerja.

Kata kunci: COVID-19, pekerja, protokol kesehatan 


\section{PENDAHULUAN}

Corona Virus Disease 2019 atau COVID-19 adalah penyakit yang disebabkan oleh virus Severe Acute Respiratory Syndrome (SARS-CoV-2). Penularan COVID-19 terjadi melalui paparan droplets yang keluar melalui napas, batuk atau bersin dari orang yang terinfeksi (WHO, 2020c). Semenjak 11 Maret 2020, WHO telah menetapkan COVID-19 sebagai pandemi (Kementerian Kesehatan RI, 2020). Pada tanggal 2 Februari 2021, total kasus kumulatif COVID-19 global mencapai 102,817,575 kasus dengan kematian sebanyak 2,227,420 kasus (WHO, 2021). Di samping itu, di Kota Surabaya, total kasus kumulatif COVID-19 hingga 2 Februari 2021 adalah 20,002 kasus dengan total kematian sebanyak 1,297 (Satuan Tugas COVID-19 Jawa Timur, 2021). Kasus konfirmasi COVID-19 Kota Surabaya masih terus mengalami peningkatan setiap harinya, sehingga perlu mendapatkan perhatian.

Salah satu kelompok yang memiliki risiko tinggi untuk tertular COVID-19 adalah kelompok pekerja. Hal ini dikarenakan beberapa pekerjaan tidak bisa dilakukan dari rumah, sehingga ketika berada di tempat kerja, pekerja berkemungkinan untuk berdekatan secara fisik dengan sesama rekan kerja, pelanggan, pasien, dan lainnya yang menyebabkan semakin tingginya risiko penularan COVID-19 pada pekerja (ECDC, 2020). Beberapa penelitian juga telah menunjukkan bahwa cluster pekerja berperan penting dalam menyumbang total kasus konfirmasi COVID-19 di berbagai negara (Huynh et al., 2020; Lan, Wei, Hsu, Christiani, \& Kales, 2020).

Pada bulan Oktober-November 2020, dilakukan pengambilan data secara online kepada 542 pekerja yang tinggal di Kota Surabaya untuk mengetahui upaya pengendalian COVID-19 yang dilakukan di tempat kerja dan risiko penularan COVID-19 di tempat kerja. Keseluruhan pekerja yang menjadi responden berasal dari 13 sektor pekerjaan dengan mayoritas bekerja di sektor pelayanan kesehatan, instansi pemerintah, pendidikan, dan jasa. Karakteristik individu yang dimiliki oleh sebagian besar responden adalah berjenis kelamin perempuan, berada dalam rentang usia 21-30 tahun, memiliki masa kerja 1-5 tahun, memiliki pendidikan terakhir di tingkat sarjana, tidak memiliki riwayat penyakit, tidak memiliki kebiasaan merokok, dan tidak dalam keadaan hamil atau sedang menyusui.

Penilaian upaya pengendalian COVID-19 di tempat kerja didasarkan pada konsep hierarchy of control. Hierarchy of control merupakan sebuah pendekatan untuk mewujudkan keselamatan dan kesehatan kerja yang tersusun dari langkah perlindungan dari yang paling efektif hingga paling tidak efektif, yang secara berurutan dari yang paling efektif terdiri dari eliminasi, substitusi, pengendalian teknis, pengendalian administratif, dan terakhir ialah alat pelindung diri (ILO, 2020a). Eliminasi adalah proses menghilangkan sumber bahaya atau menghilangkan proses yang dapat memaparkan bahaya. Pengendalian kedua adalah substitusi, yaitu mengganti bahaya atau proses yang memaparkan bahaya dengan sesuatu atau proses yang tidak lebih berbahaya, Pengendalian ketiga adalah pengendalian teknis yaitu pengendalian untuk mengurangi paparan tanpa bergantung pada perilaku pekerja. Pengendalian keempat adalah pengendalian administratif, mencakup mengubah kebijakan atau prosedur kerja untuk mengurangi paparan bahaya (ILO, 2020a). Alat pelindung diri adalah pengendalian terakhir umumnya berfungsi untuk melindungi seluruh atau sebagian tubuh pekerja terhadap kemungkinan adanya potensi bahaya atau kecelakaan kerja (Candrianto, 2020).

Risiko penularan COVID-19 di tempat kerja pada pekerja di Kota Surabaya dinilai berdasarkan upaya pengendalian yang telah dilakukan. Hasil analisis data dari 542 pekerja yang tinggal di Surabaya menunjukkan sebagian besar pekerja $(58.1 \%)$ berada dalam kategori sedang dalam menerapkan upaya pengendalian COVID-19 di tempat kerja dan masih ditemukan $10 \%$ pekerja yang berada dalam kategori kurang. Akibatnya, sebagian besar pekerja memiliki risiko penularan COVID-19 di tempat kerja dalam kategori sedang dan 10\% pekerja dalam kategori tinggi. Risiko 
penularan COVID-19 di tempat kerja dapat dikendalikan dengan menerapkan pengendalian risiko berdasarkan hierarchy of control (Hasibuan et al., 2020; ILO, 2020b). Oleh sebab itu, pengendalian COVID-19 berdasarkan hierarchy of control di tempat kerja pada pekerja di Kota Surabaya perlu diterapkan untuk mengendalikan risiko penularan COVID-19 di tempat kerja.

Tujuan dari kegiatan ini adalah mengoptimalisasi protokol kesehatan pada pekerja di Kota Surabaya, dengan menggencarkan penerapan pengendalian COVID-19 berdasarkan hierarchy of control di tempat kerja, sehingga risiko penularan COVID-19 di tempat kerja pada pekerja di Kota Surabaya dapat diminimalisasi.

\section{METODE PENGABDIAN MASYARAKAT}

Salah satu faktor penting dalam mengoptimalisasi protokol kesehatan pada pekerja di Kota Surabaya adalah mengubah perilaku pekerja. Perilaku dipengaruhi oleh banyak faktor dan Lawrence Green mengelompokkan faktor tersebut menjadi tiga, yaitu faktor predisposisi, pemungkin, dan penguat. Faktor predisposisi merupakan faktor yang ada sebelum perilaku terjadi, meliputi kepercayaan, keyakinan, pengetahuan, sikap, dan lain-lain (Nurmala, 2020). Pengetahuan dapat diubah dengan melakukan penyuluhan, karena penyuluhan pada dasarnya merupakan proses pendidikan yang memiliki tujuan mengubah pengetahuan, sikap, dan keterampilan (Febriyanti, 2020).

Metode pengabdian yang digunakan dalam kegiatan ini adalah melakukan penyuluhan dan diskusi online dengan masyarakat pekerja di Surabaya. Penyuluhan dan diskusi online dilakukan bekerja sama dengan Dinas Tenaga Kerja Kota Surabaya dan media radio RRI Surabaya. Kegiatan tersebut berlangsung pada bulan Januari 2021. Penyuluhan dan diskusi online tersebut membahas tentang rangkaian pengendalian COVID-19 di tempat kerja berdasarkan hierarchy of control yang dapat diterapkan oleh pekerja. Ddilaksanakannya kegiatan ini, diharapkan adanya perubahan perilaku pekerja untuk menerapkan pengendalian COVID-19 di tempat kerja dengan baik dan benar, sehingga protokol kesehatan dapat diterapkan secara optimal. Optimalnya protokol kesehatan pada pekerja di Kota Surabaya akan meminimalisasi risiko penularan COVID-19 pada pekerja di kota Surabaya.

\section{HASIL DAN PEMBAHASAN}

Kegiatan pengabdian masyarakat ini dilakukan kepada masyarakat pekerja di Kota Surabaya dalam bentuk penyuluhan dan diskusi online yang diberikan oleh Dosen Fakultas Kesehatan Masyarakat Universitas Airlangga, bekerja sama dengan Dinas Tenaga Kerja Surabaya dan media Radio RRI. Kegiatan penyuluhan disampaikan melalui media Radio RRI. Dalam penyuluhan tersebut disampaikan hazard identification, risk assessment, and determining control (HIRADC) untuk mengoptimalisasi penerapan protokol kesehatan pada pekerja di Surabaya dengan menerapkan pengendalian berdasarkan hierarchy of control, yaitu mencakup eliminasi, substitusi, pengendalian teknis, pengendalian administratif, dan alat pelindung diri dengan penjelasan sebagai berikut.

\section{Eliminasi}

Pengendalian eliminasi dapat dilakukan dengan tidak melakukan jabat tangan. Sebagai gantinya dapat dilakukan cara lain untuk memberi salam seperti melambaikan tangan, senyum, salam siku, dan lain-lain. Menghindari kontak fisik, termasuk berjabat tangan merupakan langkah pencegahan COVID-19 di tempat kerja yang direkomendasikan ILO dan WHO (ILO, 2020c; WHO, 2020b). Hal ini disebabkan orang sehat dapat tertular COVID-19 jika melakukan kontak 
dekat dengan orang yang terinfeksi (Phan et al., 2020). Apabila tetap dilakukan jabat tangan, maka harus segera mencuci tangan atau menggunakan hand sanitizer. Selain itu, pengendalian eliminasi juga dapat dilakukan dengan tidak melakukan perjalanan dinas ke luar daerah atau kota. Penundaan perjalanan dinas yang tidak mendesak terutama ke tempat yang terjadi penularan COVID-19 merupakan rekomendasi WHO (WHO, 2020b). Hal ini dikarenakan beberapa kasus COVID-19 dilaporkan terjadi pada orang-orang yang mengunjungi daerah yang terjadi penularan COVID-19 (European Centre for Disease Prevention and Control, 2020).

\section{Substitusi}

Pengendalian substitusi dapat dilakukan dengan memberlakukan sistem bekerja dari rumah (work from home) untuk mengurangi kemungkinan terjadinya kontak langsung antar pekerja. Selain itu, dapat pula dengan menerapkan metode absensi yang tidak memerlukan kontak fisik, seperti melakukan absensi secara online, dan menghindari metode absensi menggunakan fingerprint atau mengisi kertas absen harian. Hal ini dikarenakan SARS-CoV-2 dapat bertahan hidup dan tetap infeksius pada permukaan benda dalam waktu tertentu (Kampf, Todt, Pfaender, \& Steinmann, 2020), sehingga pada metode absensi yang memerlukan kontak fisik lebih berisiko menularkan COVID-19. Transportasi ke tempat kerja juga perlu diperhatikan, yaitu mengutamakan penggunaan transportasi pribadi atau transportasi khusus yang disediakan oleh perusahaan dan sebaiknya tidak menggunakan transportasi publik. Risiko terjadi kontak secara langsung maupun tidak langsung dengan orang lain akan meningkat ketika mengendarai transportasi publik (WHO, 2020c). Pengendalian substitusi yang lain adalah dengan mengutamakan membawa bekal pribadi untuk makan siang dan menghindari makan bersama.

\section{Pengendalian Teknis}

Pengendalian teknis yang dapat dilakukan meliputi sterilisasi rutin fasilitas umum di tempat kerja, penyediaan cairan antiseptik, penyediaan tempat cuci tangan dengan air bersih mengalir dan sabun, pengaturan jarak dan pembatasan jumlah orang ketika menggunakan lift, pemberian petunjuk naik turun pada tangga, penyediaan ruangan untuk observasi pekerja yang bergejala COVID-19, penggunaan pembatas saat melayani pelanggan secara langsung, pembuatan layout tempat kerja menjadi satu arah masuk-keluar, pengaturan jarak tempat duduk, pengaturan jarak antrean di pintu keluar masuk, dan penggunaan sistem sirkulasi yang memadai di tempat kerja.

\section{Pengendalian Administratif}

Pengendalian administratif yang dapat diterapkan di tempat kerja mencakup penyediaan dan penempelan poster edukasi terkait COVID-19, penyuluhan terkait COVID-19 kepada seluruh tenaga kerja, pengaturan jumlah pekerja yang masuk dalam satu shift, pelarangan bagi pekerja yang sakit untuk masuk kerja, pembatasan jam kerja menjadi maksimal 40 jam/minggu dengan waktu kerja harian 7-8 jam dan tidak melebihi 12 jam, kewajiban karantina mandiri bagi pekerja yang baru bepergian ke luar daerah, pelaksanaan kegiatan olah raga bersama sebelum kerja dengan tetap menjaga jarak, pembentukan tim penanganan COVID-19 di tempat kerja, kewajiban pekerja yang memiliki gejala COVID-19 untuk melapor ke tim penanganan COVID19 di tempat kerja, pengecekan suhu di pintu masuk perusahaan, pengadaan cek kesehatan rutin untuk mendeteksi dini gejala COVID-19, dan pemantauan lokasi pekerja baik secara manual maupun menggunakan aplikasi.

\section{Alat Pelindung Diri}

Alat pelindung diri yang digunakan ketika pandemi COVID-19 di tempat kerja dapat meliputi masker, face shield, sarung tangan, safety goggles, dan seragam kerja lengan panjang. Alat pelindung diri yang disarankan untuk digunakan ketika melakukan kontak dengan orang yang terinfeksi COVID-19 adalah masker, sarung tangan, gown, dan pelindung mata (goggles atau 
face shield) (WHO, 2020a). Akan tetapi, masker adalah alat pelindung diri utama yang digunakan untuk mencegah COVID-19 karena dapat mengurangi kemungkinan masuknya droplets yang terinfeksi ke dalam saluran pernapasan (Howard, Huang, Li, \& Rimoin, 2020). Hanya menggunakan safety goggles tidak dapat mencegah penularan COVID-19 (Khunti et al., 2020). Begitu pula dengan hanya menggunakan face shield tanpa masker karena masih terdapat celah untuk droplets masuk ke dalam saluran pernapasan (Verma, Dhanak, \& Frankenfield, 2020).

Ddilakukan diskusi secara online yang juga dipimpin oleh Dosen Fakultas Kesehatan Masyarakat. Diskusi tersebut membahas terkait pertanyaan pekerja seputar penerapan protokol kesehatan di tempat kerja dan membahas solusi dari kendala pekerja dalam menerapkan protokol kesehatan di tempat kerja. Dalam pelaksanaan diskusi online ini juga dibantu oleh Dinas Tenaga Kerja Surabaya.

Penyuluhan dan diskusi online tersebut berjalan dengan lancar hingga akhir kegiatan. Setelah mendapatkan penyuluhan terkait pengendalian COVID-19 di tempat kerja dan dilakukannya diskusi online terkait penerapan protokol kesehatan di tempat kerja diharapkan adanya peningkatan pengetahuan dan kesadaran pada masyarakat pekerja, sehingga hal tersebut dapat mendorong optimalisasi penerapan protokol kesehatan pada pekerja di Surabaya.

\section{PENUTUP}

\section{Kesimpulan}

Kesimpulan dari kegiatan ini yaitu optimalisasi protokol kesehatan di tempat kerja dapat diwujudkan dengan menerapkan pengendalian COVID-19 berdasarkan hierarchy of control. Kegiatan penyuluhan dan diskusi online kepada masyarakat pekerja di Kota Surabaya dapat meningkatkan pengetahuan dan kesadaran pekerja akan pentingnya penerapan pengendalian tersebut, sehingga protokol kesehatan di tempat kerja dapat diterapkan secara optimal.

\section{Saran}

Saran yang diberikan untuk perbaikan kegiatan pengabdian masyarakat terkait optimalisasi protokol kesehatan di tempat kerja adalah: 1) Menyebarluaskan hasil penyuluhan dan diskusi online ke tempat-tempat kerja di Surabaya agar seluruh pekerja dapat menerima informasi yang sama, 2) Melakukan kerja sama dengan petinggi perusahaan untuk penerapan pengendalian COVID-19 di tempat kerja.

\section{DAFTAR PUSTAKA}

Candrianto. (2020). Pengenalan Keselamatan dan Kesehatan Kerja. Batu: Literasi Nusantara.

ECDC. (2020). Covid-19 Clusters and Outbreak in Occupational Settings in the EU/EEA and the $U K$. Retrieved from https://www.ecdc.europa.eu/sites/default/files/documents/COVID-19in-occupational-settings.pdf

European Centre for Disease Prevention and Control. (2020). Outbreak of Novel Coronavirus Disease 2019 (COVID-19): Increased Transmission Globally - Fifth Updates. Stockholm: European Centre for Disease Prevention and Control.

Febriyanti, R. (2020). Penyuluhan Sosial: Membaca Konteks dan Memberdayakan Masyarakat. Bandung: Lekkas Publisher. 
Hasibuan, A., Purba, B., Mahyuddin, I. M., Sianturi, E., Armus, R., Chaerul, M., ... Jamaludin. (2020). Teknik Keselamatan dan Kesehatan Kerja. Medan: Yayasan Kita Menulis.

Howard, J., Huang, A., Li, Z., \& Rimoin, A. (2020). Face Masks Against COVID-19: An Evidence Review. Pnas.

Huynh, N. N. Y., Nguyen, D. D., Ta, N. H., Nguyen, M. T., Nguyen, T. Van, Dang, H. T., ... LE, N. T. (2020). COVID-19 Clusters at Workplaces and its Transmission into Communities in Vietnam: A Novel Emerging Occupational Risk Factor at Work Due to Coronavirus Infection. Asian Pacific Journal of Environment and Cancer, 3(1).

ILO. (2020a). A Safe and Healthy Return to Work during the COVID-19 Pandemic. Geneva: International Labour Organization.

ILO. (2020b). Dalam Menghadapi Pandemi: Memastikan Keselamatam dan Kesehatan di Tempat Kerja. Geneva: International Labour Organization.

ILO. (2020c). Kembali Bekerja dengan Aman: Panduan bagi Pengusaha untuk Pencegahan COVID-19. Jakarta: International Labour Organization.

Kampf, G., Todt, D., Pfaender, S., \& Steinmann, E. (2020). Persistence of Coronaviruses on Inanimate Surfaces and Their Inactivation with Biocidal Agents. Journal of Hospital Infection, 104(3).

Kementerian Kesehatan RI. (2020). Pedoman Pencegahan dan Pengendalian Coronavirus Disease (Covid19) (5th ed.). Jakarta: Kementerian Kesehatan RI.

Khunti, K., Trish, G., Chan, X. H., Durand-Moreau, Q., Straube, S., Devane, D., ... Adisesh, A. (2020). What is the Efficacy of Eye Protection Equipment Compared to No Eye Protection Equipment in Preventing Transmission of COVID-19-type Respiratory Illnesses in Primary and Community Care? The Centre for Evidence-Based Medicine Research.

Lan, F. Y., Wei, C. F., Hsu, Y. T., Christiani, D. C., \& Kales, S. N. (2020). Work-related COVID-19 transmission in six Asian countries/areas: A follow-up study. PLoS ONE, 15(5). https://doi.org/10.1371/journal.pone.0233588

Nurmala, I. (2020). Promosi Kesehatan. Surabaya: Airlangga University Press.

Phan, L. T., Nguyen, T. V., Luong, Q. C., Nguyen, T. V., Nguyen, H. T., \& Le, H. Q. (2020). Importation and Human-to-Human Transmission of a Novel Coronavirus in Vietnam. $N$ Eng J Med.

Satuan Tugas COVID-19 Jawa Timur. (2021). Jatim Tanggap COVID-19. Retrieved January 21, 2021, from http://infocovid19.jatimprov.go.id/\#peta

Verma, S., Dhanak, M., \& Frankenfield, J. (2020). Visualizing Droplet Dispersal for Face Shields and Masks with Exhalation Valves. Physics of Fluids, 32(9).

WHO. (2020a). Infection Prevention and Control guidance for Long-Term Care Facilities in the context of COVID-19. Retrieved from WHO/2019-nCoV/IPC_long_term_care/2020.1 
WHO. (2020b). Pertimbangan Langkah-Langkah Kesehatan Masyarakat dan Sosial di Tempat Kerja dalam Konteks COVID-19. Retrieved from https://www.who.int/docs/defaultsource/searo/indonesia/covid19/who---pertimbangan-langkah-langkah-kesehatanmasyarakat-dan-sosial-di-tempat-kerja-dalam-konteks-covid-19.pdf?sfvrsn=b8a19986_2

WHO. (2020c). Transmisi SARS-CoV-2 - Implikasi terhadap Kewaspadaan Pencegahan Infeksi: Pernyataan Keilmuan. Retrieved from https://www.who.int/docs/defaultsource/searo/indonesia/covid19/transmisi-sars-cov-2---implikasi-untuk-terhadapkewaspadaan-pencegahan-infeksi---pernyataan-keilmuan.pdf?sfvrsn=1534d7df_4

WHO. (2021). WHO Coronavirus Disease (COVID-19) Dashboard. Retrieved January 21, 2021, from https://covid19.who.int/table 